ISTIGHNA, Vol. 3, No 1, Januari 2020 P-ISSN 1979-2824 E-ISSN 2655-8459

Homepage: http://e-journal.stit-islamic-village.ac.id/index.php/istighna

Nashrul Haqqi Firmansyah

Upaya Meningkatkan Mutu PAI Melalui Kegiatan Ekstrakurikuler Keagamaan di SD

Islam se-Kota Salatiga

\title{
UPAYA MENINGKATKAN MUTU PAI MELALUI KEGIATAN \\ EKSTRAKURIKULER KEAGAMAAN DI SD ISLAM SE-KOTA SALATIGA
}

\author{
Nashrul Haqqi Firmansyah \\ nashrulhaqqi92@gmail.com \\ Institut Agama Islam Negeri Surakarta
}

\begin{abstract}
This study examines the religious extracurricular program as a means of improving the quality of Islamic Religious Education and achieving the objectives of Islamic education. Religious extracurricular activities have a positive effect on student academic achievement and can support the teaching and learning process. The existence of religious extracurricular is deemed necessary to support the achievement of the objectives of Islamic Religious Education learning. The general objective of this research is to describe religious extracurricular activities, find efforts to improve the quality of Islamic Religious Education through religious extracurricular activities and find out the factors that influence efforts to improve the quality of Islamic Religious Education through religious extracurricular activities in Islamic elementary schools in Salatiga. The researcher chose Islamic elementary school in Salatiga city because besides having a religious extracurricular program, Islamic elementary school in Salatiga city is also a school that implements Islamic values in its school environment. To get the results of the study, a descriptive method was used with a qualitative approach and observation techniques, interviews and documentation. The data of this study were sourced from the Principal, Student Waka, PAI Teachers, and Extracurricular Trainers in Islamic elementary schools in Salatiga. From this research, it was found that the implementation of Islamic Religious Education learning which was carried out, in general, went smoothly and conducive, and had already used varied learning methods. As for the implementation of religious extracurricular programs in Islamic elementary schools in Salatiga city, they differ from one school to another, with different management and strategies. In addition, each extracurricular trainer directs students to know the five aspects of the PAI curriculum not only in cognitive abilities but also in the affective and psychomotor domains. To achieve this goal, Islamic elementary schools in the city of Salatiga optimize the supporting factors and try to anticipate the existing inhibiting factors.
\end{abstract}

\section{Keyword: Religious Extracurricular; Quality of Islamic Education}

\footnotetext{
Abstrak: Penelitian ini mengkaji program ekstrakurikuler keagamaan sebagai salah satu sarana peningkatan mutu Pendidikan Agama Islam serta tercapainya tujuan pendidikan Islam. Kegiatan ekstrakurikuler keagamaan mempunyai efek 
ISTIGHNA, Vol. 3, No 1, Januari 2020 P-ISSN 1979-2824 E-ISSN 2655-8459

Homepage: http://e-journal.stit-islamic-village.ac.id/index.php/istighna

Nashrul Haqqi Firmansyah

Upaya Meningkatkan Mutu PAI Melalui Kegiatan Ekstrakurikuler Keagamaan di SD

Islam se-Kota Salatiga

positif pada prestasi akademik siswa serta dapat menunjang proses belajar mengajar. Keberadaan ekstrakurikuler keagamaan dipandang perlu guna menunjang ketercapaian tujuan pembelajaran Pendidikan Agama Islam. Tujuan umum dari penelitian ini adalah untuk mendeskripsikan kegiatan ekstrakurikuler keagamaan, Menemukan upaya peningkatkan mutu Pendidikan Agama Islam melalui kegiatan ekstrakurikuler keagamaan serta mengetahui faktor-faktor yang mempengaruhi upaya peningkatkan mutu Pendidikan Agama Islam melalui kegiatan ekstrakurikuler keagamaan di SD Islam se-kota Salatiga. Peneliti memilih SD Islam se-kota Salatiga karena disamping memiliki program ekstrakurikuler keagamaan, SD Islam se-kota Salatiga juga merupakan sekolah yang mengimplementasikan nilai-nilai Islam di lingkungan sekolahnya. Untuk mendapatkan hasil penelitian, digunakan metode deskriptif dengan pendekatan kualitatif dan tehnik observasi, wawancara serta dokumentasi. Data penelitian ini bersumber dari Kepala Sekolah, Waka Kesiswaan, Guru PAI, serta Pelatih Ekstrakurikuler di SD Islam se-kota Salatiga. Dari penelitian ini ditemukan bahwa, pelaksanaan pembelajaran Pendidikan Agama Islam yang dilaksanakan secara umum berjalan dengan lancar dan kondusif, serta sudah menggunakan metode pembelajaran yang bervariatif. Sedangkan untuk pelaksanaan program ekstrakurikuler keagamaan di SD Islam se-kota Salatiga berbeda-beda antara sekolah satu dengan yang lainya, dengan manajemen dan strategi yang berbedabeda. Selain itu setiap pelatih ekstrakurikuler mengarahkan siswa untuk mengetahui lima aspek kurikulum PAI tidak hanya dalam kemampuan kognitif saja, tetapi sampai ke ranah afektif dan psikomotorik. Guna mencapai tujuan, SD Islam se-kota Salatiga mengoptimalkan faktor pendukung serta berupaya mengentisipasi faktor penghambat yang ada.

\section{Kata Kunci: Ekstrakurikuler Keagamaan; Mutu Pendidikan Agama Islam}

\section{A. PENDAHULUAN}

Tujuan pendidikan agama Islam yang kita cita-citakan masih belum mampu diwujudkan. Hal tersebut diakibatkan masih terdapatnya kekurangan-kekurangan dalam proses pembelajaran yang dilaksanakan khususnya dalam pembelajaran PAI di kelas. Muhaimin mengemukakan beberapa kelemahan lainnya dari pendidikan agama Islam di sekolah, baik dalam pemahaman materi pendidikan agama Islam, maupun dalam pelaksanaannya. ${ }^{1}$ Nurkhalis Majid mengatakan bahwa kegagalan

\footnotetext{
${ }^{1}$ Muhaimin, Paradigma Pendidikan Islam, Bandung: Remaja Rosdakarya, 2004, 89.
} 
ISTIGHNA, Vol. 3, No 1, Januari 2020 P-ISSN 1979-2824 E-ISSN 2655-8459

Homepage: http://e-journal.stit-islamic-village.ac.id/index.php/istighna

Nashrul Haqqi Firmansyah

Upaya Meningkatkan Mutu PAI Melalui Kegiatan Ekstrakurikuler Keagamaan di SD

Islam se-Kota Salatiga

Pendidikan Agama Islam disebabkan pembelajaran PAI lebih menitikberatkan pada hal-hal yang bersifat formal dan hafalan, bukan pada pemaknaannya. ${ }^{2}$

Selain permasalahan di atas, jika kita tengok pada realita yang sebenarnya terdapat kekurangan jam pelajaran untuk pengajaran agama Islam yang disediakan di sekolah-sekolah umum seperti Sekolah Dasar, Sekolah Menengah Umum dan seterusnya. Masalah inilah yang dianggap sebagai penyebab utama timbulnya kekurangan para pelajar dalam memahami, meghayati dan mengamalkan ajaran agama. Sebagai akibat dari kekurangan ini, Nata mengatakan "para pelajar tidak memiliki bekal yang memadai untuk membentengi dirinya dari berbagai pengaruh negatif akibat globalisasi yang menerpa kehidupan". ${ }^{3}$

Maka dari itu, harus ada solusi dari permasalahan pengajaran pendidikan agama Islam tersebut, agar pendidikan agama Islam yang ada mampu menunjukan kontribusi nyata dalam menunjang keberhasilan sebuah pendidikan dan sampai kepada visi dari Pendidikan Agama Islam itu sendiri, yaitu "Menjadikan pendidikan Islam sebagai pranata yang kuat, berwibawa, efektif, dan kredibel, dalam mewujudkan cita-cita ajaran Islam”. Selain itu dengan pengajaran pendidikan Islam yang baik, diharapkan mampu membantu sekolah dalam mencetak generasi penerus yang menjadi harapan bagi bangsanya. ${ }^{4}$

Guna menunjang keberhasilan sebuah Pendidikan Agama Islam, siswa sebaiknya disibukkan dengan berbagai macam aktivitas keagamaan, salah satunya adalah kegiatan ekstrakurikuler keagamaan. Meskipun kegiatan ini bersifat ekstra, namun tidak sedikit dari kegiatan ekstrakurikuler keagamaan ini berhasil mengembangkan bakat siswa, bahkan dalam kegiatan ekstrakurikuler inilah siswa mengembangkan berbagai potensi yang dimilikinya, karena dalam ekstrakulikuler tersebut, siswa akan mendapatkan pelatihan soft skill yang tidak didapatkan di dalam kelas. Contohnya diskusi wawasan keislaman, taћsin Al-Qur'ān, kesenian islami, dan lain sebagainya. Hal tersebut sejalan dengan tujuan ekstrakurikuler yang

\footnotetext{
2 Abdul Majid \& Dian Andayani, Pendidikan Agama Islam Berbasis Kompetensi, Bandung : Rosda Karya, 2005, 165.

${ }^{3}$ Nata, A. Manajemen Pendidikan Mengatasi Kelemahan Pendidikan Agama Islam di Indonesia, Jakarta: Kencana, 2010, 18.

${ }^{4}$ Nata, A. Ilmu Pendidikan Islam, Jakarta: Kencana Prenada Media Group, 2012, 44.
} 
ISTIGHNA, Vol. 3, No 1, Januari 2020 P-ISSN 1979-2824 E-ISSN 2655-8459

Homepage: http://e-journal.stit-islamic-village.ac.id/index.php/istighna

Nashrul Haqqi Firmansyah

Upaya Meningkatkan Mutu PAI Melalui Kegiatan Ekstrakurikuler Keagamaan di SD

Islam se-Kota Salatiga

tercantum dalam Departemen Pendidikan dan Kebudayaan No. 62 Tahun 2014 pasal 2 yang berbunyi:

"Kegiatan Ekstrakurikuler diselenggarakan dengan tujuan untuk mengembangkan potensi, bakat, minat, kemampuan, kepribadian, kerjasama, dan kemandirian peserta didik secara optimal dalam rangka mendukung pencapaian tujuan pendidikan nasional". 5

Berdasarkan beberapa ulasan diatas membuat peneliti tertarik untuk mengulas sejauh mana upaya meningkatkan mutu PAI melalui kegiatan ekstrakurikuler keagamaan di SD Islam se-kota Salatiga. Gambaran yang jelas tentang arah penelitian ini secara skematis penulis gambarkan dalam kerangka berpikir sebagai berikut:

UU RI Nomor 20 Tahun 2003 tentang Sisdiknas UU RI Nomor 14 Tahun 2005 tentang Guru dan Dosen PP RI Nomor 19 Tahun 2005 tentang Standar Nasional Pendidikan PP RI

Nomor 55 Tahun 2007 tentang Pendidikan Agama dan Keagamaan

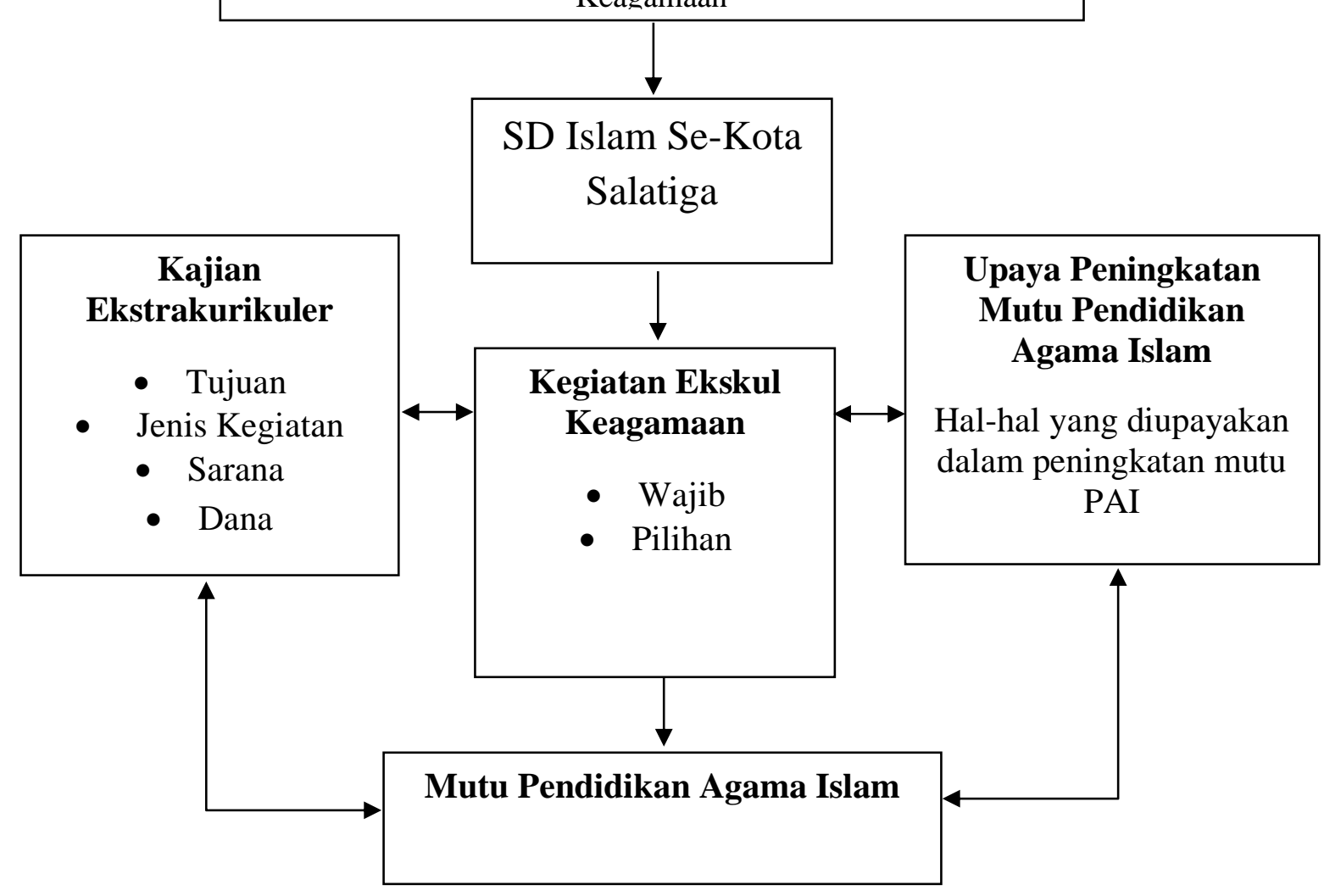

5 Departemen Pedidikan dan Kebudayaan, Permendiknud No.62 Tahun 2014 tentang Kegiatan Ekstrakuler Pada Pendidikan Dasar dan Pendidikan Menengah, Jakarta: Depdikbud. 
ISTIGHNA, Vol. 3, No 1, Januari 2020 P-ISSN 1979-2824 E-ISSN 2655-8459

Homepage: http://e-journal.stit-islamic-village.ac.id/index.php/istighna

Nashrul Haqqi Firmansyah

Upaya Meningkatkan Mutu PAI Melalui Kegiatan Ekstrakurikuler Keagamaan di SD

Islam se-Kota Salatiga

\section{B. METODOLOGI}

Untuk mendapatkan hasil penelitian, digunakan metode diskriptif dengan pendekatan kualitatif. Penelitian deskriptif adalah peelitian yang bermaksud untuk membuat gambaran mengenai situasi-situasi atau kejadian-kejadian dan mengakumulasikan data dasar dengan cara deskriptif. ${ }^{6}$

Penelitian ini dilaksanakan di SD Islam se-kota Salatiga. Adapun yang menjadi partisipan dalam penelitian ini meliputi Kepala Sekolah SD Islam se-kota Salatiga, Guru PAI di SD Islam se-kota Salatiga, Pelatih Ekstrakurikuler Keagamaan, serta Wakaur Kesiswaan. Dalam penelitian ini, penulis menggunakan metode observasi partisipatif, wawancara mendalam dan dokumentasi. Ketiga teknik tersebut digunakan dengan harapan dapat saling melengkapi antar ketiganya.

Tehnik observasi ini digunakan peneliti untuk mengamati beberapa hal terkait dengan pelaksanaan kegiatan ekstrakurikuler keagamaan dalam meningkatkan mutu Pendidikan Agama Islam di SD Islam se-kota Salatiga, diantaranya:

1. Situasi dan kondisi sekolah yang meliputi visi-misi sekolah serta sarana prasarana menyangkut kegiatan ekstrakurikuler keagamaan.

2. Situasi kegiatan pembelajaran Pendidikan Agama Islam yang dilakukan didalam dan diluar kelas.

3. Situasi kegiatan ekstrakurikuler keagamaan meliputi jadwal kegiatan, jenis kegiatan, dan pelaksanaan kegiatan.

Selanjutnya dengan tehnik wawancara, dalam hal ini peneliti menggunakan tehnik wawancara tidak terstruktur (Unstructured Interview) dengan bentuk pertanyaan yang digunakan adalah pertanyaan terbuka. Adapun informan yang diambil peneliti untuk mengetahui tentang kegiatan ekstrakurikuler keagamaan dalam meningkatkan mutu Pendidikan Agama Islam di SD Islam se-kota Salatiga adalah Kepala Sekolah SD Islam se-kota Salatiga, Guru PAI di SD Islam se-kota Salatiga, Pelatih Ekstrakurikuler Keagamaan, serta Wakaur Kesiswaan.

\footnotetext{
${ }^{6}$ Suryabrata. S, Metodologi Penelitian, Jakarta: Rajawali Pers, 2012, 76.
} 
ISTIGHNA, Vol. 3, No 1, Januari 2020 P-ISSN 1979-2824 E-ISSN 2655-8459

Homepage: http://e-journal.stit-islamic-village.ac.id/index.php/istighna

Nashrul Haqqi Firmansyah

Upaya Meningkatkan Mutu PAI Melalui Kegiatan Ekstrakurikuler Keagamaan di SD

Islam se-Kota Salatiga

Kemudian tehnik dokumentasi, adapun yang dicari oleh peneliti berupa gambaran pelaksanaan program ekstrakurikuler keagamaan. Adapun dokumentasi untuk pembelajaran Pendidikan Agama Islam diantaranya adalah proses pembelajaran di kelas serta rencana pelaksanaan pembelajaran (RPP).

Dalam penelitian ini, tahap-tahap analisis data yang digunakan peneliti berpegang pada pendapat Sugiono, yaitu Reduksi Data (Data Reduction) yang artinya merangkum, dengan memilih hal-hal yang pokok kemudian memfokuskan kepada hal-hal yang penting, selanjutnya Penyajian Data (Data Display) yaitu menyajikan data secara jelas dan singkat. Terakhir adalah Penarikan Kesimpulan dan Verifikasi (Conlusion Drawing) yang bertujuan untuk mencari makna dan data yang telah dikumpulkan, agar mendapatkan kesimpulan yang akurat. ${ }^{7}$

\section{HASIL DAN PEMBAHASAN}

\section{Pelakasanaan Pembelajaran PAI di SD Islam Se-Kota Salatiga.}

Pelaksanaan pembelajan PAI di SD Islam se-kota Salatiga dilaksanakan sesuai yang ditetapkan dalam kurikulum KTSP dan belum menerapkan kurikulum 2013. Untuk kelompok mata pelajaran Pendidikan Agama Islam maupun mata pelajaran lainnya di SD Islam se-kota Salatiga telah menetapkan standar Kriteria Ketuntasan Minimal (KKM) untuk nilai raport yang harus dicapai siswa adalah berkisar 70 sampai 75. Penetapan standar KKM ini melihat pada rata-rata tingkat kemampuan siswa dan tingkat kesulitan mata pelajarannya.

Pelaksanaan pendidikan yang dilaksanakan di seluruh SD Islam sekota Salatiga ini tidak hanya fokus terhadap aspek kognitif saja, melainkan sampai menyentuh aspek afektif dan psikomotorik. Hal ini terlihat dari adanya upaya setiap sekolah serta guru PAI untuk lebih menekankan nilainilai Islam sebagai ciri khas sekolah Islam, selain itu tujuan pembelajaran Pendidikan Agama Islam yang dilaksanakan di SD Islam se-kota Salatiga yang juga disesuaikan dengan Undang-Undang Pendidikan Nasional yang

${ }^{7}$ Sugiono, Metode Penelitian Kuantitatif, Kualitatif dan R\&D, Bandung: Alfabeta, 2010, 338-345. 
ISTIGHNA, Vol. 3, No 1, Januari 2020 P-ISSN 1979-2824 E-ISSN 2655-8459

Homepage: http://e-journal.stit-islamic-village.ac.id/index.php/istighna

Nashrul Haqqi Firmansyah

Upaya Meningkatkan Mutu PAI Melalui Kegiatan Ekstrakurikuler Keagamaan di SD

Islam se-Kota Salatiga

pada intinya adalah untuk menjadikan siswa berkarakter, berakhlakul karimah, beribadah dengan baik sesuai dengan tuntunan Al-Qur'ān dan sunah Nabi.

Proses pelaksanaan pembelajaran PAI di SD Islam se-kota Salatiga sudah menggunakan metode yang bervariatif, mulai menggunakan metode ceramah, diskusi, demonstrasi ataupun lainya, ditujukan agar siswa senantiasa dapat mengikuti pembelajaran PAI dengan kondusif, ceria dan menyenangkan sekaligus membantu siswa dalam memahami ajaran Islam secara menyeluruh.

Hal tersebut sejalan dengan yang diutarakan oleh Muhaimin, bahwa strategi penyampaian pembelajaran PAI adalah metode-metode penyampaian pembelajaran PAI yang dikembangkan untuk membuat siswa dapat merespon dan menerima pembelajaran PAI dengan mudah, cepat dan menyenangkan. Karena itu, penetapan strategi penyampaian perlu menerima serta merespon masukan dari peserta didik. Dengan demikian, strategi penyampaian mencakup lingkungan fisik, guru atau orang, bahanbahan pembelajaran dan kegiatan yang berkaitan dengan pembelajaran lain.8

Berdasarkan hasil observasi, selain guru PAI yang terus berupaya dalam mencapai tujuan pembelajaran PAI, seluruh SD Islam di kota Salatiga juga memiliki strategi khusus dalam membantu guru PAI mencapai tujuan pembelajaranya tersebut, seperti hal nya program pembiasaan PAI diantaranya peringatan hari besar keagamaan, tadarus bersama, menghafal surah-surah pilihan, sholat dhuha, sholat dzuhur berjamaah, kegiatan keagamaan di bulan ramadhan, bahkan sampai dengan mewajibkan siswa mengikuti program "Madrasah Diniyah" seperti yang di laksanakan di SD Islam Kurma dan SD Integral Hidayatullah kota Salatiga. Semuanya itu untuk meningkatkan mutu PAI serta menghasilkan out put yang mulia dan berkualitas.

\footnotetext{
${ }^{8}$ Muhaimin, Paradigma Pendidikan Islam, Jakarta: PT. Raja Grafindo Persada. 2004, 151
} 
ISTIGHNA, Vol. 3, No 1, Januari 2020 P-ISSN 1979-2824 E-ISSN 2655-8459

Homepage: http://e-journal.stit-islamic-village.ac.id/index.php/istighna

Nashrul Haqqi Firmansyah

Upaya Meningkatkan Mutu PAI Melalui Kegiatan Ekstrakurikuler Keagamaan di SD

Islam se-Kota Salatiga

2. Pelaksanaan Kegiatan Ekstrakurikuler Keagamaan di SD Islam SeKota Salatiga

Secara keseluruhan SD Islam se-Kota Salatiga berupaya mengoptimalkan potensi yang dimiliki oleh siswanya dan mewadahinya dalam kegiatan ekstrakurikuler, salah satunya adalah ekstrakurikuler keagamaan. Ekstrakurikuler keagamaan sebagai ekstrakurikuler yang mengembangkan minat dan bakat siswa dalam bidang keagamaan sebagai salah satu upaya dalam menunjang tercapainya tujuan pembelajaran Pendidikan Agama Islam.

Kegiatan ekstrakurikuler keagamaan di SD Islam se-kota Salatiga ini dilaksanakan pada sore hari setelah pulang sekolah. Pemilihan waktu pelaksanaan pada sore hari adalah agar pelaksanaan ekstrakurikuler keagamaan ini tidak mengurangi jam belajar-mengajar peserta didik, sehingga tidak akan mengganggu proses belajar mengajar. Karena pada intinya kegiatan ekstrakurikuer adalah dilaksanakan diluar jam pelajaran. Dalam pelaksanaan program ekstrakurikuler keagamaan ini, seluruh pihak SD Islam di kota Salatiga memberikan jadawal, sehingga antara kelas satu dengan yang lainya, ekstrakurikuler keagamaan satu dengan yang lainya tidak berbenturan.

Berjalanya kegiatan ekstrakurikuler keagamaan di SD Islam se-kota Salatiga sangat bervariatif antara lembaga satu dengan yang lainya, Tentunya dengan manajemen dan strategi yang bervariatif juga. Bentuk kegiatan ekstrakurikuler dikembangkan dengan mempertimbangkan tingkat pemahaman dan kemampuan peserta didik. Selain itu, SD Islam yang ada di kota Salatiga ini memfasilitasi program ekstrakurikuler sesuai dengan kebutuhan peserta didik yang ada, serta pengamatan secara mendalam minat dan bakat peserta didik.

Berpijak dari delapan bentuk kegiatan ekstrakurikuler PAI yang diterbitkan oleh Departemen Agama RI, maka penulis dapat menganalisis bahwa setiap lembaga SD Islam di kota Salatiga mengembangkan dan membagi kegiatan ekstrakurikuler keagamaan menjadi dua bagian, yaitu 
ISTIGHNA, Vol. 3, No 1, Januari 2020 P-ISSN 1979-2824 E-ISSN 2655-8459

Homepage: http://e-journal.stit-islamic-village.ac.id/index.php/istighna

Nashrul Haqqi Firmansyah Upaya Meningkatkan Mutu PAI Melalui Kegiatan Ekstrakurikuler Keagamaan di SD Islam se-Kota Salatiga

program ekstrakurikuler wajib dan pilihan. Program ekstrakurikuler wajib yaitu program yang harus diikuti oleh seluruh siswa, sedangkan yang dimaksud ekstrakurikuler pilihan adalah siswa memilih program yang sesuai dengan minat dan bakatnya. Dalam hal ini, tidak semua program ekstrakurikuler disediakan di setiap lembaga, hanya yang dibutuhkan oleh lembaga.

Dari paparan diatas, penulis dapat menggambarkan program ekstakurikuler keagamaan di SD Islam kota Salatiga dalam tabel dibawah ini.

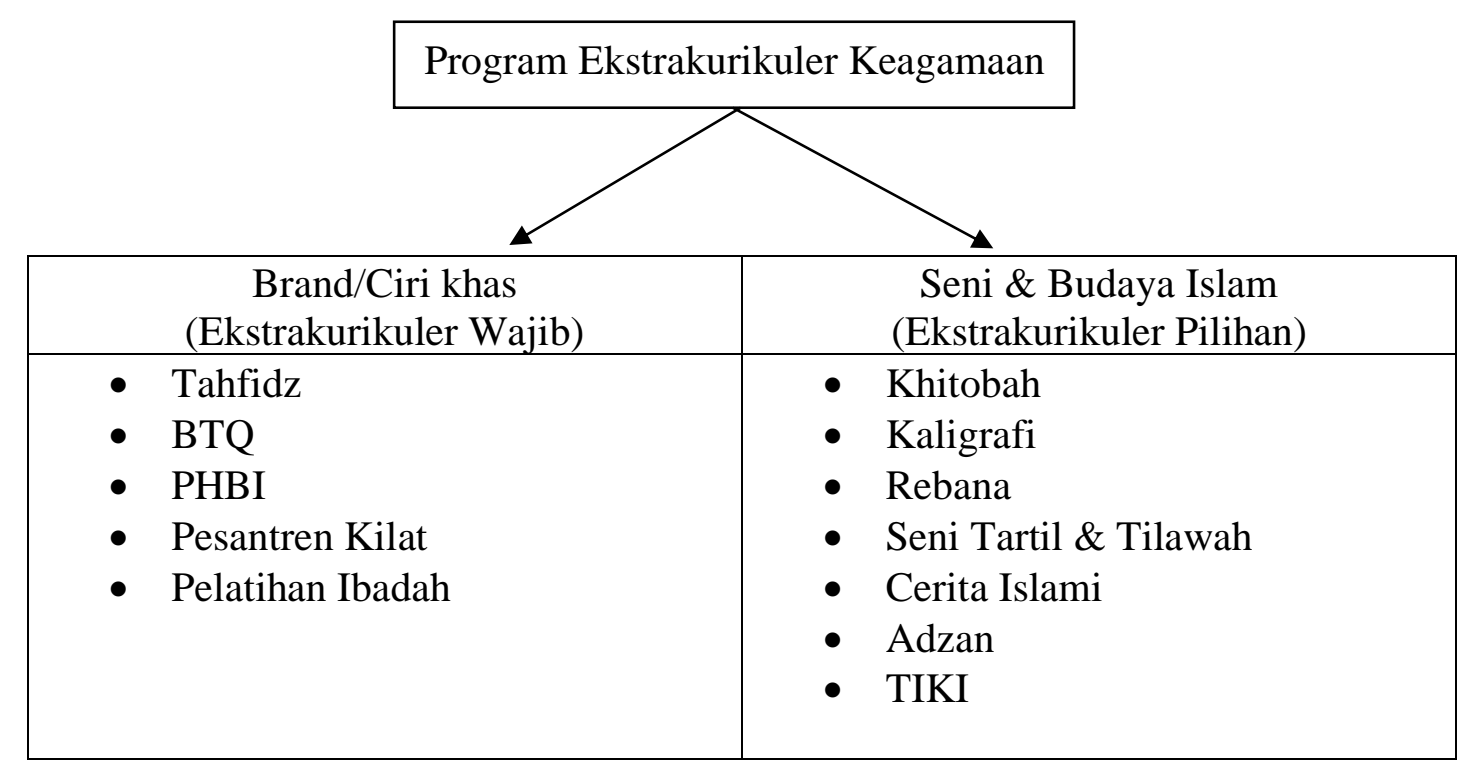

Setelah mengadakan analisis terhadap data yang diperoleh, pelaksanaan kegiatan ekstrakurikuler keagamaan di setiap SD Islam se-kota Salatiga, Jika mengacu pada panduan pelaksanaan kegiatan ekstrakurikuler Pendidikan Agama Islam pada sekolah umum yang diterbitkan oleh Departemen Agama R.I. SD Islam di kota Salatiga yang paling banyak membuat program ekstrakurikuler keagamaan adalah SD Muhammadiyah Plus dan SD Islam Kurma. Dengan rincian sebagai berikut: 
ISTIGHNA, Vol. 3, No 1, Januari 2020 P-ISSN 1979-2824 E-ISSN 2655-8459

Homepage: http://e-journal.stit-islamic-village.ac.id/index.php/istighna

Nashrul Haqqi Firmansyah Upaya Meningkatkan Mutu PAI Melalui Kegiatan Ekstrakurikuler Keagamaan di SD Islam se-Kota Salatiga

a. Program ekstrakurikuler keagamaan SD Muhammadiyah Plus \& SD Islam Kurma

\begin{tabular}{|c|c|}
\hline \multicolumn{2}{|c|}{ Daftar Program Ekstrakurikuler Keagamaan } \\
\hline SD Muhammadiyah (Plus) & SD Islam Kurma \\
\hline a. Pelatihan Ibadah & a. Pelatihan Ibadah \\
\hline b. Tahfidz & b. Tahfidz \\
\hline c. BTQ & c. BTQ \\
\hline d. Tadabbur dan Tafakkur Alam & d. Pesantren Kilat (Sanlat) \\
\hline e. Pesantren Kilat (Sanlat) & e. Kunjungan Studi. \\
\hline f. Kunjungan Studi. & f. Seni Islami \\
\hline g. Seni Islami & 1. Kaligrafi \\
\hline 1. Khitobah & 2. Tilawah \\
\hline 2. Kaligrafi & 3. Khitobah \\
\hline 3. Cerita Islami & 4. Cerita Islami \\
\hline 4. Adzan & 5. $\mathrm{CCQ}$ \\
\hline 5. Tiki & 6. Rebana \\
\hline 6. Tilawah & 7. Sholawat \\
\hline 7. CCQ & \\
\hline
\end{tabular}

b. Program ekstrakurikuler keagamaan di SD Al-Azhar, SDIT Nida'ul Hikmah, SD Integral Hidayatullah dan SD Tahfidz adalah sebagai berikut:

\begin{tabular}{|c|c|c|c|}
\hline \multicolumn{4}{|c|}{ Daftar Program Ekstrakurikuler Keagamaan } \\
\hline SD Al-Azhar & $\begin{array}{l}\text { SDIT Nida'ul } \\
\text { Hikmah }\end{array}$ & SD Tahfidz an-Nida & $\begin{array}{c}\text { SD Integral } \\
\text { Hidayatullah }\end{array}$ \\
\hline $\begin{array}{ll}\text { a. } & \text { Pembiasaan } \\
& \text { Ibadah } \\
\text { b. } & \text { Tahfidz } \\
\text { c. BTQ } \\
\text { d. Pesantren Kilat } \\
\text { e. Kunjungan Studi. } \\
\text { f. Seni Islami } \\
\text { 1. Rebana } \\
\text { 2. Qiro'ah }\end{array}$ & $\begin{array}{ll}\text { a. Pelatihan Ibadah } \\
\text { b. Tahfidz } \\
\text { c. BTQ } \\
\text { d. Kunjungan } \\
\text { Studi. } \\
\text { e. Seni Islami } \\
\text { 1. Tartil } \\
\text { 2. Qiro'ah } \\
\text { 3. Kaligrafi } \\
\text { 4. Adzan }\end{array}$ & $\begin{array}{ll}\text { a. Pelatihan Ibadah } \\
\text { b. Tahfidz } \\
\text { c. BTQ } \\
\text { d. PHBI } \\
\text { e. Seni Islami } \\
\text { 1. Tartil } \\
\text { 2. Qiro'ah } \\
\text { 3. Kaligrafi }\end{array}$ & $\begin{array}{ll}\text { a. } & \text { Pelatihan Ibadah } \\
\text { b. } & \text { Tahfidz } \\
\text { c. } & \text { Tartil } \\
\text { d. } & \text { BTQ } \\
\text { e. } & \text { Pesantren Kilat } \\
\text { f. } & \text { PHBI }\end{array}$ \\
\hline
\end{tabular}

Dari data diatas, maka SD Muhammadiyah Plus \& SD Islam Kurma lebih leluasa dalam meningkatkan mutu Pendidikan Agama Islam melalui program ekstrakurikuler keagamaan. Selain banyaknya 
ISTIGHNA, Vol. 3, No 1, Januari 2020 P-ISSN 1979-2824 E-ISSN 2655-8459

Homepage: http://e-journal.stit-islamic-village.ac.id/index.php/istighna

Nashrul Haqqi Firmansyah

Upaya Meningkatkan Mutu PAI Melalui Kegiatan Ekstrakurikuler Keagamaan di SD Islam se-Kota Salatiga

program ekstrakurikuler keagamaan yang diampu, dua sekolah ini juga sangat memperhatikan SDM pengampu program ekstrakurikuler keagamaan. Karena banyaknya program ekstrakurikuler tidak akan ada manfaatnya jika tidak di atur dan di kelola dengan baik.

Pelaksanaan program ekstrakurikuler keagamaan di SD Al-Azhar, SDIT Nida'ul Hikmah, SD Tahfidz an-Nida' dan SD Integral Hidayatullah belum maksimal, sehingga perlu upaya-upaya khusus yang harus dilakukan guna meningkatkan mutu Pendidikan Agama Islam. Di empat SD Islam diatas lebih mengupayakan peningkatan mutu Pendidikan Agama Islam melalui kegiatan lain selain ekstrakurikuler, seperti program Madin di SD Integral Hidayatullah dan SD Tahfidz an-Nida' serta program pembiasaan dan pengembangan diri di SD Al-Azhar dan SDIT Nida'ul Hikmah.

\section{Upaya Meningkatkan Mutu PAI Melalui Kegiatan Ekstrakurikuler} Keagamaan di SD Islam Se-Kota Salatiga.

Sebelum lebih jauh membahas tentang upaya meningkatkan mutu Pendidikan Agama Islam melalui kegiatan ekstrakurikuler keagamaan di SD Islam se-kota Salatiga, maka perlu diketahui bahwa kurikulum Pendidikan Agama Islam di sekolah terdiri atas beberapa aspek, yaitu aspek Al-Qur'an Hadits, keimanan atau aqidah, akhlak, fiqih ( hukum Islam), dan aspek Tarikh (sejarah). Meskipun masing-masing aspek tersebut dalam prakteknya saling mengaitkan atau terkait (mengisi dan melengkapi), tetapi jika dilihat secara teoritis masing-masing memiliki karakteristik tersendiri sebagai berikut: ${ }^{9}$

a. Aspek Al-Qur'an dan Hadist, menekankan pada kemampuan baca tulis yang baik dan benar, memahami makna secara tekstual, serta mengamalkan kandungannya dalam kehidupan sehari-hari.

\footnotetext{
${ }^{9}$ Muhaimin, Rekontruksi Pendidikan Islam, Jakarta : rajawali Press, 2009, 33.
} 
ISTIGHNA, Vol. 3, No 1, Januari 2020 P-ISSN 1979-2824 E-ISSN 2655-8459

Homepage: http://e-journal.stit-islamic-village.ac.id/index.php/istighna

Nashrul Haqqi Firmansyah

Upaya Meningkatkan Mutu PAI Melalui Kegiatan Ekstrakurikuler Keagamaan di SD

Islam se-Kota Salatiga

b. Aspek Aqidah, menekankan pada kemampuan memahami dan mempertahankan keyakinan atau keimanan yang benar serta menghayati dan mengamalkan nilai-nilai asma' alhusna.

c. Aspek Akhlak, menekankan pada pembiasaan untuk melaksanakan akhak terpuji dan menjahui akhlak tercela dalam kehidupan sehari-hari.

d. Aspek Fiqih, menekankan pada kemampuan cara melaksanakan ibadah dan muamalah yang benar dan baik.

e. Aspek Tarikh dan kebudayaan islam, menekankan pada mengambil ibrah (contoh atau hikmah) dari peristiwa-peristiwa bersejarah (Islam), meneladani tokoh-tokoh berprestasi, dan mengaitkannya dengan fenomena-fenomena sosial, budaya, politik, ekonomi, iptek, dan lainlain untuk mengembangkan kebudayaan dan peradapan Islam.

Untuk mencapai aspek kurikulum Pendidikan Agama Islam di atas, pihak sekolah di setiap SD Islam di kota Salatiga tentunya melakukan inovasi-inovasi kurikulum, penambahan jam pelajaran, serta meningkatkan kemampuan dan keterampilan siswa melalui program ekstrakurikuler. Setelah tercapainya beberapa aspek tersebut maka Pendidijan Agama Islam harus mengembangkan konsep keterpaduan antara ketercapaian kemampuan yang bersifat kognitif, afektif maupun psikomotorik. Kemudian menyangkut upaya meningkatkan mutu Pendidikan Agama Islam melalui kegiatan ekstrakurikuler keagamaan di SD Islam se-kota Salatiga, penulis mendapatkan hasil penelitian sebagai berikut:

a. Upaya meningkatkan mutu PAI dari ekstrakurikuler keagamaan wajib.

1) Upaya meningkatkan mutu PAI melalui program ekstrakurikuler Tahfidz

Didalam program ekstrakurikuler tahfidz ini banyak strategi yang bisa dilakukan untuk meningkatkan mutu Pendidikan Agama Islam, diantaranya:

a) Guru memberikan penekanan makhorijul huruf dan tajwid dalam membaca al-Qur'an. Sehingga siswa akan terpacu untuk membaca al-Qur'an dengan tuntunan dan tajwid yang benar. 
ISTIGHNA, Vol. 3, No 1, Januari 2020 P-ISSN 1979-2824 E-ISSN 2655-8459

Homepage: http://e-journal.stit-islamic-village.ac.id/index.php/istighna

Nashrul Haqqi Firmansyah

Upaya Meningkatkan Mutu PAI Melalui Kegiatan Ekstrakurikuler Keagamaan di SD

Islam se-Kota Salatiga

b) Guru membaca ayat al-Qur'an, siswa menirukan.

c) Mudarosah kelompok. Yaitu anak dibagi menjadi beberapa kelompok, setiap kelompok mendengarkan dan menyimak bacaan al-Qur'an yang dibacakan oleh setiap siswa secara bergantian.

d) Hafalan, setelah siswa membaca dengan benar maka guru meminta setiap siswa untuk menghafalkan sesuai target yang harus dihafalkan.

e) Setoran, siswa yang sudah hafal diminta untuk menyetorkan kepada guru. Disini guru juga memberikan motivasi agar siswa lebih semangat dalam belajar dan menghafal al-Qur'an.

f) Dalam meningkatkan kemampuan afektif dan psikomotorik siswa, maka guru membantu siswa untuk memahami dan menghayati al-Qur'an sampai dengan pengamalanya dalam kehidupan sehari-hari.

Dari beberapa upaya diatas, SD islam di kota Salatiga menganggap bahwa program ekstrakurikuler tahfidz ini sangat efisien dalam meningkatkan mutu Pendidikan Agama Islam. Sehingga aspek alQuran dan Hadits dalam kurikulum Pendidikan Agama Islam terpenuhi, bahwasanya siswa mempunyai kemampuan baca tulis yang baik dan benar, memahami makna secara tekstual, serta mengamalkan kandungannya dalam kehidupan sehari-hari.

2) Upaya meningkatkan mutu PAI melalui program ekstrakurikuler BTQ

Berdasarkan hasil dari pengamatan dan wawancara, penulis mendapatkan gambaran bahwasanya upaya meningkatkan mutu PAI melalui kegiatan BTQ ini adalah: Melalui metode Qiro'ati yang digunakan oleh SD Islam Kurma dan SDIT Nida'ul Hikmah adalah bahwasanya siswa dituntun untuk belajar membaca al-Quran sesuai dengan panduan Qiroati dari pusat. Metode ini dirasa lebih sulit dibandigkan dengan metode Iqra' maupun metode yang lain, 
ISTIGHNA, Vol. 3, No 1, Januari 2020 P-ISSN 1979-2824 E-ISSN 2655-8459

Homepage: http://e-journal.stit-islamic-village.ac.id/index.php/istighna

Nashrul Haqqi Firmansyah

Upaya Meningkatkan Mutu PAI Melalui Kegiatan Ekstrakurikuler Keagamaan di SD

Islam se-Kota Salatiga

meskipun demikian bacaan al-Qur'an anak juga dirasa jauh lebih baik dikarenakan setiap lafadz hija'iyah diberikan penekanan yang benar. Didalam metode ini setelah pembelajaran ada pentaskhehan bacaan yang akan di taskheh oleh guru Qiro'ati.

Melalui metode Iqra' yang digunakan oleh SD Muhammadiyah (Plus), SD Al-Azhar, dan SD Integral Hidayatullah adalah siswa dituntun untuk belajar membaca al-Qur'an sesuai dengan panduan Iqra'. Bagi siswa yang belum bisa membaca al-Qur'an akan dituntun untuk belajar membaca al-Qur'an mulai dari Iqra' jilid 1 sampai dengan jilid 6. Baik melalui metode Qiro'ati maupun metode Iqra' keduanya sama-sama baik, keduanya sangat membantu siswa dalam belajar membaca dan memahami al-Qur'an.

Sedangkan utuk melatih siswa dalam menulis huruf arab adalah, melalui program ekstrakurikuler BTQ ini guru menerapkan metode pembiasaan. disetiap harinya setiap siswa diberikan tugas untuk menulis atau menyalin mushaf al-Qur'an dalam bentuk tulisan tangan diluar jam pembelajaran. Dengan demikian siswa akan terbiasa dalam menulis Arab.

3) Upaya meningkatkan mutu PAI melalui program ekstrakurikuler PHBI

Upaya yang ada untuk meningkatkan mutu Pendidikan Agama Islam melalui program ekstrakurikuler PHBI adalah, SD Islam yang memiliki program ekstrakurikuler PHBI membuat kegiatan baik pengajian atau sebagainya. Kegiatan ini akan melatih peserta didik untuk selalu berperan serta dalam upaya-upaya menyemarakkan syiar islam dalam kehidupan masyarakat melalui kegiatan-kegiatan yang positif dan bernilai baik bagi perkembangan internal ke dalam lingkungan masyarakat yang lebih luas. Sedangkan untuk meningkatkan kemampuan afektif dan psikomotorik siswa, guru memberikan pemahaman tentang sejarah islam yang diharapkan siswa akan mampu mengambil ibrah (contoh atau hikmah) dari 
ISTIGHNA, Vol. 3, No 1, Januari 2020 P-ISSN 1979-2824 E-ISSN 2655-8459

Homepage: http://e-journal.stit-islamic-village.ac.id/index.php/istighna

Nashrul Haqqi Firmansyah

Upaya Meningkatkan Mutu PAI Melalui Kegiatan Ekstrakurikuler Keagamaan di SD

Islam se-Kota Salatiga

peristiwa-peristiwa bersejarah, meneladani tokoh-tokoh berprestasi, dan mengaitkannya dengan fenomena-fenomena sosial, budaya, politik, ekonomi, iptek, dan lain-lain untuk mengembangkan kebudayaan dan peradapan Islam.

4) Upaya meningkatkan mutu PAI melalui program ekstrakurikuler Pesantren Kilat

Semua SD Islam se-kota Salatiga mengagendakan kegiatan ini pada setiap bulan Ramadhan dan diberi nama "Pesantren Ramadhan". Sehingga momen di bulan Ramadhan ini sangat membantu untuk di isi dengan kegiatan-kegiatan yang bersifat keagamaan. Dalam program ekstrakurikuler pesantren kilat ini upaya yang dilakukan adalah:

a) Untuk meningkatkan kemampuan kognitif siswa, guru membuat kegiatan pengkajian dan diskusi agama.

b) Sedangkan untuk meningkatkan kemampuan afektif dan psikomotorik siswa, guru mewajibkan siswa untuk buka dan sahur bersama, shalat terawih berjamaah, tadarus al-Qur'an, holat tahajud, bakti sosial dan sebagainya.

Dari upaya diatas, diharapkan kegiatan ekstrakurikuler pesantren kilat ini akan memeberi pemahaman yang menyeluruh tentang pentingnya menghidupkan hari-hari dan malam-malam ramadhan serta mengamalkanya dengan kegiatan positif. Kegiatan pesantren kilat ini dilaksanakan dengan mengasramakan para siswa agar bisa mengikuti program selama 24 jam.

5) Upaya meningkatkan mutu PAI melalui program ekstrakurikuler pelatihan ibadah.

Program ekstrakurikuler Pelatihan Ibadah yang ada di SD Islam sekota Salatiga mengacu pada aktifitas-aktifitas yang tercakup dalam rukun islam, yaitu membaca dua kalimat syahadat, sholat, zakat, puasa dan haji serta ditambah dengan bentuk-bentuk ibadah lainnya yang sifatnya sunnah. 
ISTIGHNA, Vol. 3, No 1, Januari 2020 P-ISSN 1979-2824 E-ISSN 2655-8459

Homepage: http://e-journal.stit-islamic-village.ac.id/index.php/istighna

Nashrul Haqqi Firmansyah

Upaya Meningkatkan Mutu PAI Melalui Kegiatan Ekstrakurikuler Keagamaan di SD

Islam se-Kota Salatiga

Upaya meningkatkan mutu Pendidikan Agama Islam yang dilakukan setiap SD Islam di kota Salatiga diantaranya adalah:

a) Untuk meningkatkan kemampuan kognitif siswa, guru mewajibkan siswa untuk menghafalkan doa-doa serta mengetahui syarat dan ketentuan ibadah yang akan dilaksanakan

b) Untuk meningkatkan kemampuan afektif siswa, guru menuntun siswa untuk menghayati, dan meresapi setiap ibadah yang dilakukan siswa.

c) Untuk meningkatkan kemampuan psikomotorik siswa, guru mewajibkan sholat dhuha setiap hari, melaksanakan sholat dhuhur berjamaah setiap hari, melaksanakan manasik haji sesuai dengan waktu yang ditentukan setiap sekolah, mengadakan mabit, serta pembagian zakat.

Dari upaya yang ada di atas, diharapkan kegiatan pelatihan ketrampilan pengamalan ibadah ini akan menjadikan siswa sebagai muslim yang disamping berilmu juga mampu mengamalkan ajaran agamanya dalam kehidupan sehari-hari, sehingga siswa mampu untuk melaksanakan ibadah dan muamalah yang benar dan baik sesuai dengan tujuan kurikulum Pendidikan Agama Islam.

b. Upaya meningkatkan mutu PAI dari ekstrakurikuler keagamaan pilihan

1) Upaya meningkatkan mutu PAI melalui program ekstrakurikuler Khitobah

Khitobah merupakan program ekstrakurikuler pilihan di SD Islam se kota Salatiga. Program ekstrakurikuler ini kebanyakan diikuti oleh siswa yang mempunyai keberanian dan kepercayaan diri yang lebih. Berdasarkan hasil pengamatan dan wawancara terhadap sekolah yang memiliki program ekstrakurikuler ini penulis mendapatkan keterangan bahwa upaya yang diberikan untuk meningkatkan mutu Pendidikan Agama Islam diantaranya adalah:

a) Untuk meningkatkan kemampuan kognitif siswa, guru meminta siswa untuk mencari dan membaca dalil-dalil yang bersumber 
ISTIGHNA, Vol. 3, No 1, Januari 2020 P-ISSN 1979-2824 E-ISSN 2655-8459

Homepage: http://e-journal.stit-islamic-village.ac.id/index.php/istighna

Nashrul Haqqi Firmansyah

Upaya Meningkatkan Mutu PAI Melalui Kegiatan Ekstrakurikuler Keagamaan di SD

Islam se-Kota Salatiga

dari al-Quran dan Hadis dengan benar dan nada yang baik, menghafalkan hadits-hadits tematik, menyimak dan membaca teks khitabah berbagai tema dengan intonasi yang baik, serta meminta siswa untuk mencipta teks pidato Islam secara sederhana.

b) Untuk meningkatkan kemampuan afektif siswa, guru memberikan pemahaman kepada siswa, bahwasanya tugas pendakwah itu selain memberikan mau'idhoh hasanah juga harus mampu mengamalkan dalam kehidupan sehari-hari.

c) Untuk meningkatkan kemampuan psikomotorik siswa, guru meminta siswa untuk tampil berpidato, baik dalam event lomba, pidato di lingkungan sekolah maupun berpidato untuk kegiatan keagamaan di masyarakat.

Melalui upaya di atas, secara tidak langsung pengetahuan siswa terhadap Pendidikan Agama Islam akan bertambah, sehingga hasil belajar dalam bidang Pendidikan Agama Islam pun akan meningkat. Selain itu keberanian dan kepercayaan diri siswa akan terpupuk sejak kecil, bahkan akan memberikan motivasi lebih jika siswa menjuarai berbagai lomba yang diikuti.

2) Upaya meningkatkan mutu PAI melalui program ekstrakurikuler Kaligrafi

Dari seluruh program ekstrakurikuler keagamaan yang ada, SD Islam di kota salatiga memasukan ekstrakurikuler kaligrafi kedalam ekstrakurikuler pilihan. Kaligrafi merupakan seni Islami yang perlu untuk di lestarikan dan dikembangkan. Melalui program ini, ada beberapa upaya untuk meningkatkan mutu Pendidikan Agama Islam di SD Islam se-kota Salatiga, diantaranya adalah:

a) Untuk mengembangkan kemampuan kognitif siswa, guru memperkenalkan kepada siswa bentuk bentuk huruf hijaiyah serta memberikan pemahaman terhadap ayat-ayat al-Qur'an yang ditulis siswa. 
ISTIGHNA, Vol. 3, No 1, Januari 2020 P-ISSN 1979-2824 E-ISSN 2655-8459

Homepage: http://e-journal.stit-islamic-village.ac.id/index.php/istighna

Nashrul Haqqi Firmansyah

Upaya Meningkatkan Mutu PAI Melalui Kegiatan Ekstrakurikuler Keagamaan di SD

Islam se-Kota Salatiga

b) Untuk mengembangkan kemampuan afektif siswa, guru menanamkan sikap cinta dan menjaga budaya Islam yang ada.

c) Untuk mengembangkan kemampuan psikomotorik siswa, guru mengajarkan kepada siswa cara menulis dengan indah dan benar.

Serta memberikan kepercayaan kepada siswa untuk mengikuti perlombaan kaligrafi guna menambah wawasan dan pengalaman siswa.

Melalui beberapa upaya diatas, diharapkan siswa akan terbiasa jika dihadapkan dengan soal menulis Arab, karena Pendidikan Agama Islam tidak lepas dari membaca, memahami serta menulis huruf Arab.

3) Upaya meningkatkan mutu PAI melalui program ekstrakurikuler Rebana

Seni rebana merupakan seni Islami yang populer di kalangan masyarakat. Alat musik yang dimainkan adalah perkusi, cara memainkanya adalah di pukul dengan meyelaraskan nada. Seni rebana biasa digunakan untuk mengiringi lagu-lagu sholawat. Di SD Islam se-kota Salatiga megadakan kegiatan rebana dalam bentuk ekstrakurikuler memang sangatlah penting untuk memenuhi dan ikut berpartisipasi di bidang keagamaan di masyarakat.

Adapun upaya yang diberikan untuk meningkatkan mutu Pendidikan Agama Islam melalui ekstrakurikuler rebana di SD Islam se-kota Salatiga yaitu memberikan pemahaman kepada siswa melalui sholawat yang di nyanyikan. Guru ekstrakurikuler rebana di SD Islam kota Salatiga ini tidak hanya dituntut untuk melatih memainkan rebana saja, tapi mampu memberikan pemahaman terhadap siswa tentang sholawat yang dinyanyikan, sehingga siswa mengetahui sejarah, perjalanan nabi dan umat terdahulu serta mampu mengambil ibrah dari kisah yang dijelaskan oleh guru.

4) Upaya meningkatkan mutu PAI melalui program ekstrakurikuler seni Tartil \& Tilawah. 
ISTIGHNA, Vol. 3, No 1, Januari 2020 P-ISSN 1979-2824 E-ISSN 2655-8459

Homepage: http://e-journal.stit-islamic-village.ac.id/index.php/istighna

Nashrul Haqqi Firmansyah

Upaya Meningkatkan Mutu PAI Melalui Kegiatan Ekstrakurikuler Keagamaan di SD Islam se-Kota Salatiga

Program ekstrakurikuler seni tartil dan tilawah ini sangat penting untuk dilaksanakan di setiap SD Islam di kota Salatiga, guna meningkatkan mutu Pendidikan Agama Islam. Mempu membaca alQur'an dengan baik dan indah adalah tuntunan yang harus dimiliki oleh setiap umat muslim. Adapun upaya meningkatkan mutu Pendidikan Agama Islam melalui program ekstrakurikuler seni tartil dan tilawah di SD Islam se-kota Salatiga diantaranya yaitu:

a) Untuk meningkatkan kemampuan kognitif siswa, Guru mengajarkan membaca dengan nada indah serta mengecek bacaan al-Qur'an setiap siswa. Siswa yang kurang benar dalam membaca al-Qur'an akan diberikan penekanan ke tajwid maupun makhorijul huruf.

b) Guru mengajarkan siswa mebaca al-Qur'an dengan memvariasi nada-nada yang indah, misalnya menggunakan nada Hijaz, Bayati, Qoror, Nahawan dan lain sebagainya. dalam hal ini diharapkan siswa mempunyai variasi yang banyak tentang nadanada tilawah sehingga bacaan al-Qur'am akan enak untuk didengar.

c) Sedangkan dalam meningkatkan kemampuan afektif dan psikomotorik siswa, maka guru membantu siswa untuk memahami dan menghayati al-Qur'an sampai dengan pengamalanya dalam kehidupan sehari-hari.

Dari beberapa upaya yang ada diatas diharapkan akan dapat meningkatkan mutu pendidikan agama Islam, khususnya untuk memenuhi aspek al-Qur'an dan Hadits di SD Islam se-kota Salatiga.

5) Upaya meningkatkan mutu PAI melalui program ekstrakurikuler Cerita Islami

Program ekstrakurikuler cerita Islami di SD Islam se-kota salatiga bertujuan untuk menjembatani dan memfasilitasi siswa dalam persiapan lomba Pekan Maulid dan Mapsi. Pekan Maulid merupakan program yang diselenggarakan oleh KKG PAI se kota 
ISTIGHNA, Vol. 3, No 1, Januari 2020 P-ISSN 1979-2824 E-ISSN 2655-8459

Homepage: http://e-journal.stit-islamic-village.ac.id/index.php/istighna

Nashrul Haqqi Firmansyah

Upaya Meningkatkan Mutu PAI Melalui Kegiatan Ekstrakurikuler Keagamaan di SD

Islam se-Kota Salatiga

Salatiga guna menjaring dan mengembangkan bakat siswa dalam

bidang Pendidikan Agama Islam, sedangkan Mapsi adalah program

yang diselenggarakan Dinas Pendidikan Jawa Tengah yang

bertujuan mengembangkan keterampilan seni pada siswa di seluruh

sekolah dasar yang berada di wilayah Jawa Tengah.

Meskipun demikian, program ini sangat penting untuk meningkatkan aspek kognitif, afektif dan psikomotorik dalam bidang Pendidikan Agama Islam. Melalui program ekstrakurikuler cerita islami ini siswa di ajak untuk bercerita sambil bermain peran, sehingga anak lebih bisa menjiwai tokoh-tokoh islam yang sedang di ceritakan. Upaya yang ada pada ekstrakurikuler ini sebenarnya hampir sama dengan upaya yang ada pada program PHBI dan Rebana, yaitu sama-sama mengambil ibrah dari tokoh-tokoh islam yang berprestasi, tetapi dalam hal ini cerita islami lebih mendalam karena anak di ajak untuk mengetahui, menceritakan, memerankan sampai dengan mengambil ibrah daripada cerita-cerita Islam.

6) Upaya meningkatkan mutu PAI melalui program ekstrakurikuler Adzan

Program ekstrakurikuler adzan ini hanya dilaksanakan di SD Muhammadiyah Plus. Didalam program ekstrakurikuler adzan ini upaya yang dilakukan pelatih adzan di SD Muhammadiyah Plus diantara lain adalah:

a) Pelatih adzan di SD Muhammadiyah Plus diampu oleh Qori' nasional yang mempunyai jam terbang yang bagus dalam hal qori' dan adzan.

b) Dalam meningkatkan kemampuan kognitif siswa, guru mengajarkan bagaimana mengumandangkan adzan dengan baik, selain itu guru menuntun siswa untuk mengetahui arti setiap lafadz adzan.

c) Dalam menningkatkan kemampuan afektif siswa, guru memberikan stimulus kepada siswa untuk menghayati setiap lafadz adzan. Sehingga tertanam dalam diri siswa untuk menambah kecintaan siswa terhadap sang pencipta 
ISTIGHNA, Vol. 3, No 1, Januari 2020 P-ISSN 1979-2824 E-ISSN 2655-8459

Homepage: http://e-journal.stit-islamic-village.ac.id/index.php/istighna

Nashrul Haqqi Firmansyah

Upaya Meningkatkan Mutu PAI Melalui Kegiatan Ekstrakurikuler Keagamaan di SD

Islam se-Kota Salatiga

d) Sedangkan dalam meningkatkan kemampuan psikomotorik siswa, guru membiasakan anak untuk ikut andil dalam mengumandangkan adzan di masjid-masjid yang terjangkau.

Dari beberapa upaya diatas, tujuanya yaitu anak lebih mampu memahami dan menghayati aspek aqidah dalam Pendikan Agama Islam.

7) Upaya meningkatkan mutu PAI melalui program ekstrakurikuler TIKI

Program ekstrakurikuler ini hanya dilaksanakan di SD Muhammadiyah Plus. Upaya-upaya yang dilakukan pelatih TIKI di SD Muhammadiyah Plus diantaranya yaitu:

a) Pelatih program ekstrakurikuler TIKI di SD Muhammadiyah Plus diampu oleh pelatih yang ahli dalam bidang informatika, selain itu didukung oleh kemampuan yang bagus dibidang keagamaan

b) Untuk mengembangkan kemampuan kognitif siswa, pelatih memberikan arahan tentang bagaimana menulis Arab dan menggunakan tehnologi dengan baik sesuai dengan yang diajarkan umat Islam

c) Untuk mengembangkan sikap afektif siswa, pelatih menjelaskan mengapa umat Islam itu harus meguasai tehnologi, serta bagaimana umat Islam menggunakan tehnologi untuk kemaslahatan umat. Sedangkan dalam mengembangkan kemampuan psikomotorik, pelatih mengarahkan siswa untuk ikut dalam perlombaan-perlombaan untuk lebih memotivasi siswa.

Dari beberapa upaya diatas, diharapkan tujuan Pendidikan Agama Islam dalam aspek Tarikh, sejarah dan tehnologi Islam dapat tercapai, karena kemajuan adalah tujuan dari seluruh umat Islam.

\section{Faktor Pendukung dan Penghambat Upaya Pengembangan Mutu PAI Melalui Kegiatan Ekstrakurikuler Keagamaan di SD Islam Se-Kota} Salatiga.

Agar pelaksanaan kegiatan ekstrakurikuler keagamaan di SD Islam se-kota Salatiga dapat terlaksana dengan baik dan memperoleh hasil serta manfaat yang optimal sesuai dengan tujuan pembelajaran, Untuk lebih 
ISTIGHNA, Vol. 3, No 1, Januari 2020 P-ISSN 1979-2824 E-ISSN 2655-8459

Homepage: http://e-journal.stit-islamic-village.ac.id/index.php/istighna

Nashrul Haqqi Firmansyah Upaya Meningkatkan Mutu PAI Melalui Kegiatan Ekstrakurikuler Keagamaan di SD Islam se-Kota Salatiga

jelasnya penulis akan mengungkapkan faktor pendukung dan penghambat sebagai berikut:

a. Faktor Pendukung.

Berdasarkan hasil wawancara dari beberapa Kepala Sekolah di SD Islam se-kota Salatiga, bahwa faktor pendukung untuk bisa terwujudnya peningkatan mutu Pendidikan Agama Islam melalui kegiatan ekstrakurikuler keagamaan di SD Islam se-kota Salatiga adalah:

1) Media dan Sarana prasarana yang memadai, baik mushola/masjid yang dapat menampung siswa untuk melaksanakan sholat berjamaah dan praktik ibadah, aula dan ruangan yang dimanfaatkan untuk kegiatan ekstrakurikuler keagamaan, al-Qur'an serta bukubuku pendukung lainya.

2) Dukungan yang lebih oleh komite sekolah terhadap berjalanya program ekstrakurikuler keagamaan.

3) Guru Pendidikan Agama Islam dan SDM pengampu program ekstrakurikuler yang berkompeten.

4) Kepercayaan masyarakat terhadap SD Islam di kota Salatiga sangat tinggi.

5) Dukungan orang tua yang selalu memotivasi anaknya untuk mengikuti kegiatan serta mendorong agar hadir di setiap pelaksanaan kegiatan.

6) Dukungan yang baik dari administrasi dan teknis kegiatan ekstrakurikuler.

Sedangkan hasil wawancara dari beberapa guru PAI dan pengampu program ekstrakurikuler keagamaan di SD Islam se-kota Salatiga yang penulis dapatkan yaitu:

1) Komitmen pihak sekolah yang tinggi untuk meningkatkan mutu pendidikan Islam dari hari ke hari sesuai dengan kemampuan dan sarana prasarana yang ada. 
ISTIGHNA, Vol. 3, No 1, Januari 2020 P-ISSN 1979-2824 E-ISSN 2655-8459

Homepage: http://e-journal.stit-islamic-village.ac.id/index.php/istighna

Nashrul Haqqi Firmansyah

Upaya Meningkatkan Mutu PAI Melalui Kegiatan Ekstrakurikuler Keagamaan di SD

Islam se-Kota Salatiga

2) Menempatkan seseorang dalam melaksanakan tugas sesuai dengan kemampuan dan keahliannya masing-masing.

3) SD Islam di kota salatiga selalu unggul dalam bidang Pendidikan Agama Islam, dibuktikan dari hasil perlombaan yang ada.

4) Tersedianya sarana dan prasarana yang dibutuhkan oleh pihak sekolah.

5) Komitmen guru dan karyawan untuk meningkatkan mutu, melalui kekompakan dan kerjasama yang baik dengan pihak yang terkait.

Hal inilah sebagai alasan/pertimbangan yang utama bagi orang tua memasukkan anaknya sekolah ke SD Islam di kota Salatiga, karena lebih mengutamakan pendidikan Islam baik secara kurikulum maupun secara hidup bermasyarakat, dengan membuktikan rasa keislaman dalam pergaulan serta pembinaan akhlak anak.

b. Faktor Penghambat

Faktor penghambat di setiap SD Islam se-kota salatiga sangat berbeda-beda. Dibawah ini penulis mencoba menguraikan beberapa faktor yang didapatkan dari hasil observasi dan wawancara, diantaranya adalah:

1) Adanya ekstrakurikuler lain yang diikuti siswa, sehingga siswa tidak bisa terfokus kepada satu ekstrakurikuler keagamaan.

2) Sustainability guru/pengampu ekstrakurikuler. Hal ini terlihat dari semangat guru yang diawal sangat bersemangat, namun ditengahtengah tidak terlalu bersemangat lagi.

3) Beban belajar siswa yang terlalu berat, sehingga siswa banyak yang mengeluh dan tidak maksimal untuk menguasai pelajaran Pendidikan Agama Islam.

4) Lingkungan tempat tinggal anak yang kurang baik.

5) Pembebanan anak terhadap prestasi lomba, sehingga acuan untuk peningkatan mutu Pendidikan Agama Islam tidak terlalu diperhatikan.

Schwartz, menyebutkan bahwa tidak mungkin untuk mencapai

keberhasilan yang besar tanpa menjumpai perlawanan, kesukaran dan

kemunduran. Akan tetapi adalah mungkin untuk menjalani hidup anda selebihnya tanpa kekalahan. Adalah mungkin untuk menggunakan 
ISTIGHNA, Vol. 3, No 1, Januari 2020 P-ISSN 1979-2824 E-ISSN 2655-8459

Homepage: http://e-journal.stit-islamic-village.ac.id/index.php/istighna

Nashrul Haqqi Firmansyah

Upaya Meningkatkan Mutu PAI Melalui Kegiatan Ekstrakurikuler Keagamaan di SD

Islam se-Kota Salatiga

kemunduran sebagai pendorong anda untuk maju. ${ }^{10}$ Upaya peningkatan mutu Pendidikan Agama Islam juga tidak akan tercapai tanpa kesabaran dan usaha yang keras. Sedangkan ekstrakurikuler keagamaan adalah salah satu wadah dan strategi untuk mengembangkan mutu Pendidikan Agama Islam.

\section{KESIMPULAN}

Berdasarkan hasil penelitian di lapangan, baik melalui wawancara, pengamatan, dan dokumentasi, pelaksanaan pembelajan PAI di SD Islam se-kota Salatiga dilaksanakan sesuai yang ditetapkan dalam kurikulum KTSP dengan menetapkan KKM berkisar antara 70 sampai 75. Selain itu pembelajaran PAI tidak hanya fokus terhadap aspek kognitif saja, melainkan sampai menyentuh aspek afektif dan psikomotorik, serta menggunakan metode yang bervariatif. Hal ini terlihat dari adanya upaya setiap sekolah serta guru PAI untuk lebih menekankan nilai-nilai Islam sebagai ciri khas sekolah Islam.

Pelaksanaan kegiatan ekstrakurikuler keagamaan di SD Islam se-kota Salatiga berbeda-beda antara sekolah satu dengan yang lainya, dengan manajemen dan strategi yang berbeda-beda. Seluruh SD Islam di kota salatiga membagi kegiatan ekstrakurikuler keagamaan menjadi dua, yaitu kegiatan ekstrakurikuler wajib dan pilihan. Disini ekstrakurikuler keagamaan seni budaya Islam merupakan ekstrakurikuler yang dijadikan ekstrakurikuler pilihan, sedangkan tujuh ekstrakurikuler lainya diantaranya pelatihan Ibadah, TTQ, PHBI, TTA, pesantren kilat, kegiatan perpustakaan, dan kunjungan studi, merupakan ekstrakurikuler yang wajib harus diikuti oleh seluruh siswa.

Upaya peningkatan mutu PAI melalui kegiatatan ekstrakurikuler keagamaan di SD Islam se-kota Salatiga adalah untuk memenuhi lima aspek kurikulum PAI, yaitu aspek Al-Qur'an Hadits, keimanan atau aqidah, akhlak, fiqih ( hukum Islam), dan aspek Tarikh (sejarah). Setiap pelatih ekstrakurikuler mengarahkan siswa untuk mengetahui lima aspek kurikulum PAI tidak hanya dalam kemampuan kognitif saja, tetapi sampai ke ranah afektif dan psikomotorik.

${ }^{10}$ Schwartz, J.D. Berfikir dan Berjiwa Besar. Batam: Bina Rupa Aksara, 2007, 327. 
ISTIGHNA, Vol. 3, No 1, Januari 2020 P-ISSN 1979-2824 E-ISSN 2655-8459

Homepage: http://e-journal.stit-islamic-village.ac.id/index.php/istighna

Nashrul Haqqi Firmansyah Upaya Meningkatkan Mutu PAI Melalui Kegiatan Ekstrakurikuler Keagamaan di SD Islam se-Kota Salatiga

Faktor-faktor yang mempengaruhi upaya peningkatkan mutu PAI melalui kegiatan ekstrakurikuler keagamaan di SD islam se-kota Salatiga diantaraya yaitu faktor pelatih ekstrakurikuler, sarana prasarana, dukungan setiap sekolah dan orang tua siswa, serta komitmen seluruh guru dan karyawan untuk meningkatkan mutu, melalui kekompakan dan kerjasama yang baik dengan pihak yang terkait.

\section{REFERENSI}

Abdul Majid \& Dian Andayani, (2005), Pendidikan Agama Islam Berbasis Kompetensi, Bandung: Rosda Karya.

Departemen Pedidikan dan Kebudayaan, Permendiknud No.62 Tahun 2014 tentang Kegiatan Ekstrakuler Pada Pendidikan Dasar dan Pendidikan Menengah, Jakarta: Depdikbud.

Muhaimin, (2004), Paradigma Pendidikan Islam, Bandung: Remaja Rosdakarya. (2009), Rekontruksi Pendidikan Islam, Jakarta : rajawali Press.

Nata, A. (2012), Ilmu Pendidikan Islam , Jakarta: Kencana Prenada Media Group. (2010), Manajemen Pendidikan Mengatasi Kelemahan Pendidikan Agama Islam di Indonesia, Jakarta: Kencana.

Schwartz, J.D. (2007), Berfikir dan Berjiwa Besar. Batam: Bina Rupa Aksara. Sugiono, (2010), Metode Penelitian Kuantitatif, Kualitatif dan R\&D, Bandung: Alfabeta.

Suryabrata. S, (2012), Metodologi Penelitian, Jakarta: Rajawali Pers. 